\title{
Effect of paid work on health in opinions of Polish adolescents aged 14-15
}

\author{
Stanisław Lachowski ${ }^{1, A-F}$, Bogusława Lachowska ${ }^{2, A, C-F} \oplus$ \\ ${ }^{1}$ Maria Curie-Sklodowska University, Lublin, Poland \\ 2 The John Paul II Catholic University of Lublin, Lublin, Poland \\ A - Research concept and design, B - Collection and/or assembly of data, C - Data analysis and interpretation, \\ $D$ - Writing the article, $E$ - Critical revision of the article, $F$ - Final approval of article
}

Lachowski S, Lachowska B. Effect of paid work on health in opinions of Polish adolescents aged 14-15. Ann Agric Environ Med. 2018; 25(4): 672-679. doi: $10.26444 /$ aaem/95216

\begin{abstract}
Introduction. The positive aspects of work of the underaged are perceived as including its economic value, positive role in the process of upbringing and socialization, and in the process of vocational training or economic education. However, on the other hand, attention is also paid to the negative consequences of work, such as threats to psychophysical and intellectual development, risk to health or even life, of the adolescents.

Materials and method. The basis for this study was a survey conducted in a group of Polish adolescents aged 14-15 years. The study was conducted during 2016-2017 in a representative group of 5,468 schoolchildren from junior high schools, selected by the method of stratified sampling. The research material was collected using a questionnaire for the assessment of the phenomenon of economic activity among adolescents.

Results. The results of the study showed that approximately $20 \%$ of Polish adolescents aged $14-15$ performed paid work as hired labour, about 30\% helped with running a family business (family farm, family business), and nearly $20 \%$ of respondents undertook independent economic activity. The majority of economically active adolescents are of the opinion that the work performed exerts a positive effect on their health. Evaluation of the work activities performed as dangerous, worse state of health of adolescents, and lower parameters of their physical development, exert the greatest effect on the perception of a given work as negatively affecting health. Negative evaluations of the effect of work on health also shape the perception of work as severe and experience of accident at work.

Conclusions. These results may be used for the elaboration of practical recommendations in order to reduce negative effects, and enhance positive effects which work exerts on adolescents' health.
\end{abstract}

Key words

adolescents, underage labour, attitude to work, health

\section{INTRODUCTION}

The issue of underage labour, especially of children, occurred at the beginning of the $19^{\text {th }}$ century during the period of intensive development of industry in America and Europe [1]. This period was characterized by a high demand for workers and, simultaneously, a tendency to minimize labour costs. Despite the fact that two centuries have elapsed since those times, in many regions of the world the problem of underage labour has not been solved, although the International Labour Organization (ILO) statistics show that at the beginning of the 21st century, worldwide, a considerable limitation was observed in the phenomenon of underage labour. In 2000, 211 million children aged from 5-14 (17.6\% of the total number of children at this age) were engaged in economic activity [2]. In 2004 , the number of working children at this age decreased by approximately 20 million, compared to the year 2000 [2]. In the subsequent years, the number of economically active children systematically decreased - down to 130 million in 2016 (compared to 2000 - a decrease by 80.7 million - i.e. by $38.2 \%)[3,4]$.

Although in recent years the phenomenon of employment of children aged up to 14 has been clearly limited, at the same time, in 2016 worldwide, every tenth child at this age

Address for correspondence: Stanisław Lachowski, Maria Curie-Sklodowska University, Lublin, Poland

e-mail: stlachowski@wp.pl

Received: 23.08.2018; accepted: 18.09.2018; first published: 13.11.2018 was economically active, and $2.9 \%$ of children performed dangerous jobs or work creating a hazard to their health and development [4].

Some researchers emphasize that the data by the ILO or the World Bank concerning the phenomenon of underage labour are incomplete, because they do not cover the situations in which children are engaged in unpaid work in family enterprises, on private farms or in households $[5,6]$.

In Poland, the phenomenon of underage labour, i.e. employment of persons aged under 18, has been poorly recognized. The data are only available concerning the employment of adolescents, i.e. individuals aged 15 but not over 18. These persons can undertake jobs based on principles in the Labour Code [7]. Separate regulations pertain to the employment of adolescents on family farms. According to the Act in the matter of farmers' social insurance [8], persons aged 16 and over, who are children of the owners of private farms, are considered as household members with full right to social insurance.

In Poland, similar to other countries worldwide, the scale of illegal employment of children on the so-called 'grey market' is not known. The situation of engagement of those underage on family farms is specific. This form of labour is neither subject to any specific legal regulations, nor is it covered by statistics concerning underage labour. Only the Farmers' Social Insurance Fund (KRUS) by the year 2004 kept statistics concerning accidents among children aged up to 15 who helped their parents with agricultural jobs [9], 
which showed that each year farmers reported approximately 1,400 accidents involving children, of which about 1,000 were considered as accidents in children during agricultural work activities. Comprehensive research concerning the phenomenon of engagement of children in agriculture were conducted within statutory activity of the Institute of Rural Health in selected regions of Poland (Lublin and Bydgoszcz) $[10,11,12]$ These studies showed that nearly all children from agricultural families aged between 11-14 were engaged in work on a farm. Farmers' children performed many varied jobs, including those considered as dangerous and hazardous, such as the operation of agricultural machinery and tractors, tending large animals, or use of chemical agents [13].

Work by those underage, generating earnings or income for them or their families, causes much controversy. Positive aspects of underage labour are perceived, including its economic value $[14,15]$, and the positive effect of work in the process of upbringing and socialization, vocational training, and also economic education of children and adolescents [16]. Underage labour is being accepted and considered positive if it does not exert a negative effect on somatic health, development and maturation of a young person, and does not interfere with his/her functioning at school [17]. However, on the other hand, attention is paid to the negative aspects of work, such as threats to psychophysical development [18, 19], intellectual development, threat to health or even life of a young person $[20,21]$. A study conducted in 83 developing countries among children aged between 10-14 showed a significant positive relationship between the work of children and mortality among adolescents [22]. The researchers suggest that one of the causes of higher mortality among adolescents is the too early undertaking of employment not adjusted to their capabilities. In addition, the work of children is negatively correlated with the state of health of the population, which confirms the hypothesis concerning the negative effect of excessive loading with work at a young age on human health.

\section{OBJECTIVE}

The aim of the study is presentation of the opinions of Polish adolescents aged between 14-15 concerning the effect on their health of jobs undertaken to obtain earnings or income. In addition, the authors indicate the factors related with adolescents' opinions concerning the relationship between work performed and their health.

\section{MATERIALS AND METHOD}

The basis for analysis of the scope of problems undertaken was a survey conducted during 2016-2017, among Polish adolescents aged from $14-15$, on a representative sample of 4,568 junior high school adolescents by the method of stratified sampling. The sample is representative for Polish adolescents at this age from the aspect of five characteristics: age, gender, place of residence (rural, urban), administrative region of residence.

Research material was collected using a questionnaire for assessment of the phenomenon of economic activity of adolescents. The questionnaire consisted of eight thematic blocks, the first five concerning assessment of the scale of the phenomenon of undertaking various forms of economic activity. In the subsequent block of items, individual types of activity were assessed from seven aspects, three of which concerned health:

1) assessment of the severity of work activities performed;

2) assessment of safety while performing work activities;

3) assessment of the effect of work on health.

The above-mentioned aspects were analysed according to a 5-degree scale. The last block concerns demographic and psychosocial characteristics of the examined adolescents, as well as the socio-demographic characteristics of their families.

Analyses of the results obtained were performed using statistical software IBM SPSS v.24. The research material was analysed using stepwise linear regression analysis and Mann-Whitney test.

\section{RESULTS}

In the conducted study, the undertaking of work activities providing income or earnings by adolescents aged 14-15 was considered as a manifestation of economic activity. This concept refers mainly to adults; however, in Poland it also covers adolescents aged 15-18. The Main Statistical Office (GUS) considers as economically active persons aged 15 and over who, within the period of one week covered by the study performed for at least one hour, work providing income or earnings, which means that they were employed as hired labour, worked on their own (or leased) farm, or ran own business activity outside agriculture. These are also persons who helped (without payment) in running a family farm or family business outside agriculture [23].

Based on the above, for the needs of the study it was adopted that adolescents performing work activities providing income or earnings are individuals who undertake at least one of three types of work:

1) paid work activities (payment in the form of cash or in kind) outside the family (hired labour);

2) work activities performed within a family business activity (farm or other business outside agriculture);

3) independent economic activity (e.g. collection of recyclable materials, collection of forest undergrowth, trade, educational services, etc.).

During the study, the time of performing the abovementioned activities was determined during three periods directly preceding the study: within a week, month, and during summer vacations.

Analysis of the phenomenon of economic activity among Polish adolescents showed its considerable variation according to the type of work activities performed, and the period preceding the study which was taken into account: a week, month, vacations. It was found that during the week preceding the study a relatively low percentage of adolescents (approximately 14\%) undertook hired work or independent economic activity, while a considerably higher percentage of adolescents (25.1\%) undertook work on behalf of family economic activity. Assistance with running a family business was provided by $26.3 \%$ of adolescents within the month preceding the study, and $28.9 \%$ of adolescents during summer vacations. With respect to the performance of hired labour, 


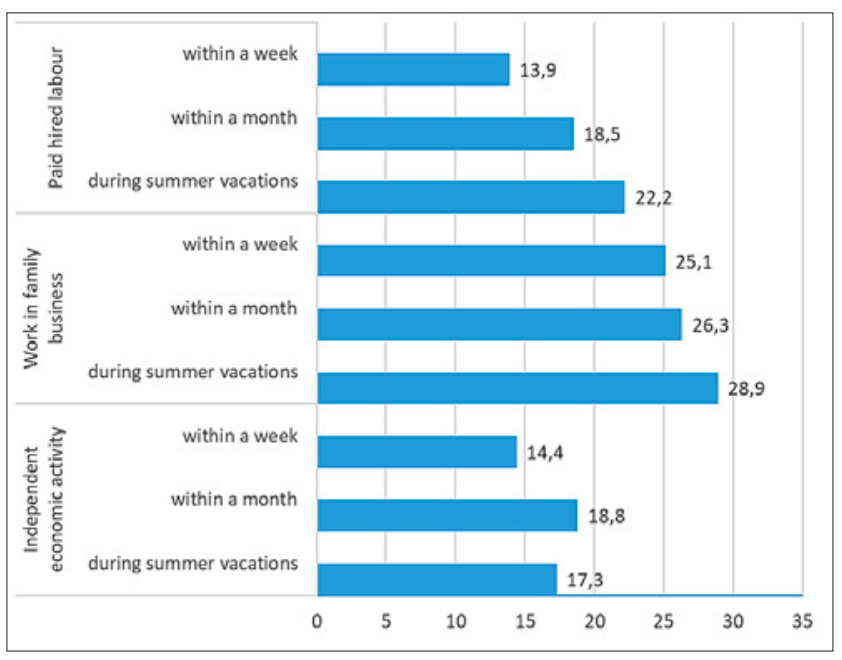

Figure 1. Percentage of adolescents undertaking work activities according to the type of work and period of its performance

the percentage of adolescents engaged in these work activities also increased when observation was for a longer period of time. Within a month preceding the study, these work activities were performed by $18.5 \%$ of adolescents, and during vacations $-22.2 \%$. Summer vacation is a period of higher economic activity of adolescents with respect to the performance of hired labour and work activities in a family business. The percentage of adolescents undertaking independent business activity was very similar within the period of one month (18.85\%) and during vacations (17.3\%), whereas it was slightly lower within the period of one week preceding the study (14.4\%).

While analyzing the mean time of performing work per person engaged in a given type of work, it was observed that the adolescents in the study devoted the greatest amount of time to the performance of paid (hired) labour, and work in a family business or on a farm (Tab. 1). The mean working time of one person was approximately eight hours within a week, 20 work hours in a month, and approximately 50 hours during summer vacations. Adolescents devoted considerably less time to independent economic activity. Independent activity, on average, occupied approximately three hours less within one week, about seven hours less in one month, and approximately 23 hours less during the summer vacation.

In the case of many forms of activity, differences in time devoted to work activities by the adolescents in the study were observed according to the place of residence (Tab. 1).
Rural adolescents devoted more time to economic activity, compared to urban adolescents, and in the case of the majority of the periods and forms of activity analyzed, these differences were statistically significant. During the summer vacation and within a month preceding the study, the working time of rural adolescents was significantly higher than that of urban adolescents, for all forms of activity analyzed. It should be emphasized that rural adolescents devoted a greater amount of time than urban adolescents helping their parents in running a business, and this concerned all periods analyzed (week, month, vacation). This result is largely due to the considerable commitment of rural adolescents to work activities on a farm. However, only with respect to hired labour and independent activity undertaken within a week preceding the study, no differences in work were observed according to the place of residence.

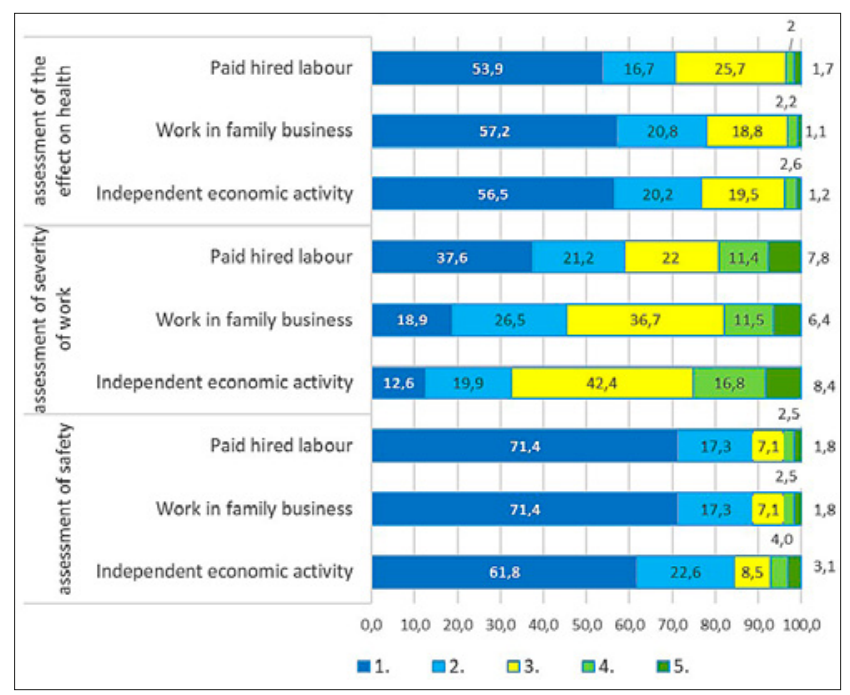

Figure 2. Assessment of the effect of work activities performed by adolescents on their health and assessment of the severity and safety of work activities performed Legend: rating scales

assessment of the effect on health: 1 - positive effect to 5 - negative effect assessment of severity of work: 1 - light to 5 - hard

assessment of safety: 1 - safe to 5 - dangerous

Adolescents undertaking various forms of economic activity evaluated in what way the work activities performed affected their state of health. In addition, the work activities performed were assessed from the aspects of their severity and safety. Evaluations from these aspects are related with health, because both an excessive loading with work and

Table 1. Mean time of performing various types of work activities according to place of residence.

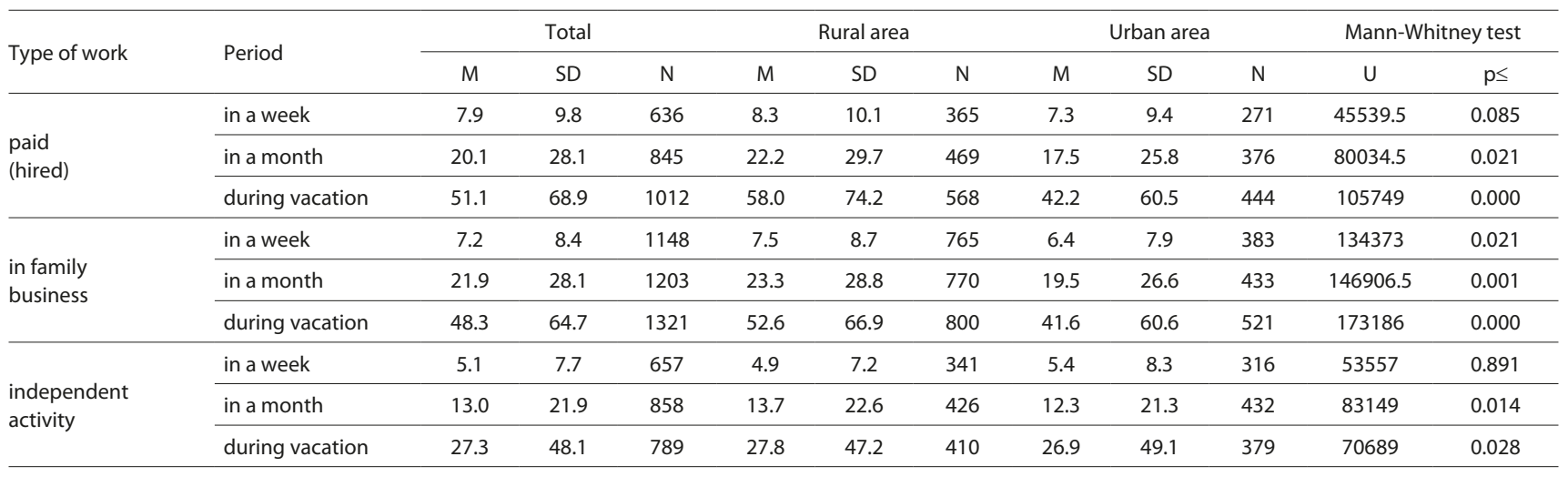


exposure to hazardous factors may exert a negative effect on the health of persons performing such work. The respondents provided evaluations according to a 5-degree scale, where 1 meant an extremely positive evaluation, while 5 - extremely negative (Fig. 1).

The data obtained showed that the majority of adolescents (approximately 70\%) evaluated the work activities they performed as completely safe, while approximately $1 / 5$ of respondents evaluated them as rather safe. A relatively low percentage of adolescents (from 5-7\%) mentioned that the performed work activities were rather hazardous or dangerous. The evaluations of various types of work activities were similar, whereas great differences were observed with respect to evaluations of the severity of individual jobs. Every third respondent evaluated the hired labour as light or rather light (33.5\%), and approximately $1 / 4$ as rather severe or hard (25.2\%). The reminder (42.4\%), indicated a middle value on the evaluation scale, determining that the work performed was neither severe nor light. Compared to other types of work, the highest percentage of adolescents evaluated hired labour as hard. A lower percentage of respondents indicated that work activities performed to the benefit of a family business (17.9\%), or within independent economic activity (19.2\%), were rather severe or hard (Fig. 1).

Adolescents' evaluations of the effect of work activities performed on their health was similar in the case of each type of work analyzed. The evaluations of the effect on health of hired work, work in family business were similar. More than a half of the economically active respondents reported that the work activities performed positively affected their health, approximately $1 / 5$ of them considered that the effect of work was rather positive, whereas only about $4 \%$ of respondents admitted that work exerted a negative effect on their health. The reminder - approximately $20 \%$ - mentioned that work did not affect their health.
In order to identify the factors shaping adolescents' evaluations of the work performed by them on own health, stepwise multiple linear regression was applied. The stepwise method consists in an introduction of predictors into the model, in the subsequent steps, automatically according to the model statistics. In addition, when after the introduction of the subsequent predictor it occurs that the previous one loses its importance, it is removed from the model [24].

Analyses were performed three times, with respect to the assessment of the effect on health of three various types of work: hired labour, work to the benefit of a family business and a family farm, and work performed within independent economic activity. In each analysis, the same set of explaining (independent) variables was introduced. The variables introduced into the model were: respondent's gender, age, place of residence (urban - rural), working time within a week, during a month, and summer vacation preceding the study, being involved in an accident while performing work, evaluation of the family material standard, adolescents' selfreported state of health and physical fitness, the respondents' height and body weight, assessment of the severity and safety of the performed work activities by the adolescents, as well as three types of motivation: material, resulting from the need for development, and pressure from the environment. Each motivation was represented by a separate dichotomous variable.

According to the conducted analyses, adolescents who performed hired labour evaluated the effect on own health more negatively, the more they perceived these work activities as hazardous $(\beta=0.203)$, and the more negatively they evaluated own physical fitness $(\beta=0.194)$ (Tab. 2). With respect to the effect on health of work activities performed to the benefit of family businesses and farms, the analysis generated a model containing five variables significantly related with this evaluation. It was found that according to

Table 2. Models of predictors for adolescents' evaluations of the effect of work performed on their own health in the total population examined (results of stepwise linear regression)

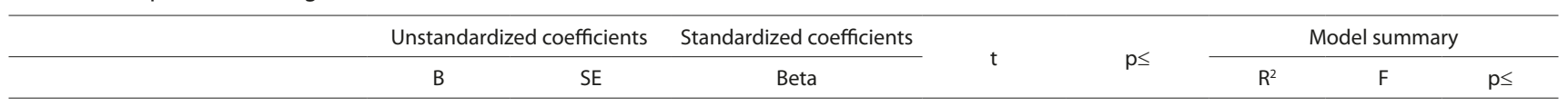

Model of predictors for the health effect of hired labour

\begin{tabular}{lcccccc}
\hline (Constant) & 1.080 & .091 & & 11.921 & 0.000 & \\
\hline Evaluation of safety of paid work & .190 & .034 & .203 & 5.594 & 0.000 & 0.077 \\
\hline Physical fitness & .220 & .041 & .194 & 5.344 & 0.000 & 0.000 \\
\hline
\end{tabular}

Model of predictors for the health effect of work in family business

\begin{tabular}{lccccc}
\hline (Constant) & 1.1 & 0.116 & 9.463 & 0.000 \\
\hline Evaluation of safety & 0.18 & 0.034 & 0.166 & 5.306 & 0.000 \\
\hline Motivation for work development & -0.359 & 0.062 & -0.171 & -5.757 & 0.000 \\
\hline Self-reported state of health & 0.169 & 0.037 & 0.137 & 4.541 & 0.000 \\
\hline Evaluation of severity of work & 0.067 & 0.026 & 0.082 & 2.628 & 0.009 \\
\hline Accident at work & 0.143 & 0.064 & 0.070 & 2.254 & 0.024 \\
\hline
\end{tabular}

Model of predictors for the health effect of independent economic activity

\begin{tabular}{lccccc}
\hline (Constant) & 1.240 & .114 & 10.849 & 0.000 \\
\hline $\begin{array}{l}\text { Evaluation of safety of independent } \\
\text { economic activity }\end{array}$ & .177 & .038 & .202 & 4.614 & 0.000 \\
\hline Evaluation of physical fitness & .143 & .053 & .119 & 2.713 & 0.053 \\
\hline Working time during a month & -.004 & .002 & -.091 & -2.078 & 0.007 \\
\hline
\end{tabular}


adolescents, the effect of work activities of this type on health was more positive if these activities were undertaken in view of own development $(\beta=-0.171)$, while it was more negative the greater the degree of perceiving them as hazardous $(\beta=0.166)$, the more negative evaluation of own state of health $(\beta=0.137)$ the more severe these activities $(\beta=0.082)$, and in the case of previous experience of accident at work $(\beta=0.070)$.

Analysis of the factors explaining the evaluation of the effect of work performed by adolescents within independent economic activity on their health generated a model containing three variables significantly related with this evaluation (Tab. 2). Based on the conducted analyses, it was found that the effect of this type of work on health was evaluated by the adolescents in more negative terms the bigger the number of dangers and hazards related with work $(\beta=202)$, and the more negative assessment of own physical fitness $(\beta=0.119)$. At the same time, the fact of devoting a larger amount of time to such activity resulted in a more positive evaluation of the effect of this work on health $(\beta=-0.091)$.

The adolescents' place of residence (urban/rural) was not related with the evaluation of the effect of work activities performed on health. Nevertheless, a question was posed whether the factors shaping such an evaluation differed according to the place of residence. In order to obtain an answer to this question, stepwise linear regression was performed for each type of work in the groups of rural and urban adolescents. The same explaining variables which were considered during analyses performed in the whole group, were introduced into the model, apart from the variable concerning the place of residence (rural/urban) (Tab. 3, 4).

In the groups of urban and rural adolescents, the models of conditioning of the evaluations concerning the effect of work performed on health contain some predictors which are the same, but simultaneously contain a different number of predictors included in individual models, and the models differ by the percentage of the explained variability of evaluation of the effect of work on health.

In the model of conditioning of adolescents' evaluations of the effect of hired labour on their health there occurred two predictors which were the same: evaluation of work safety and self-reported physical fitness (Tabs. 3, 4). The direction of the relationship between these variables and the explaining variable was the same in both models. Motivation for undertaking work also occurred in models for both groups. In the group of urban adolescents, the relationship was observed between evaluation of the effect of hired labour on health and the motive - undertaking work wishing for development. Indication of this motive was related with more positive evaluation of the effect of work on health. In the group of rural adolescents, undertaking work under pressure on the part of the environment was related with evaluation. Indication of this motive was related with a more negative assessment of the effect of work on health. In the group of rural adolescents, there occurred another predictor specific of this group, i.e. body weight. It was observed that the higher the adolescent's body weight, the more positive the assessment of the effect of work on health.

In the model of conditioning of adolescents' evaluations of the effect of work in family business on health, in the group of rural and urban adolescents there occurred the same two predictors: development as a motive for work and selfreported state of health. In both models, the undertaking of work due to the possibility of own development was related

Table 3. Models of predictors for adolescents' evaluations of the effect of work performed by them on own health in the group of urban inhabitants (results of stepwise linear regression)

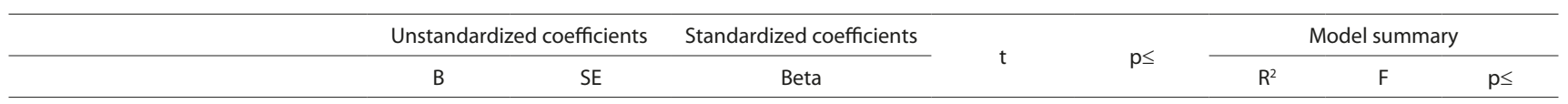

Model of predictors for the health effect of hired labour

\begin{tabular}{lcccccc}
\hline (Constant) & 1.339 & .161 & 8.313 & 0.000 \\
\hline Evaluation of physical development & .244 & .056 & .233 & 4.336 & 0.000 & 0.118 \\
\hline Evaluation of safety of work activities & .169 & .052 & .173 & 3.220 & 0.001 \\
\hline Motivation for work - development & -.313 & .120 & -.140 & -2.612 & 0.009 \\
\hline
\end{tabular}

Model of predictors for the health effect of work in family business

\begin{tabular}{lccccc}
\hline (Constant) & 1.155 & .178 & 6.486 & 0.000 \\
\hline Motivation for work - development & -.470 & .099 & -.227 & -4.740 & 0.000 \\
\hline Evaluation of severity of work & .144 & .040 & .178 & 3.637 & 0.000 \\
\hline Self-reported state of health & .170 & .059 & .141 & 2.881 & 0.138 \\
\hline Accident at work & .227 & .096 & .116 & 2.376 & 0.018 \\
\hline
\end{tabular}

Model of predictors for the health effect of independent economic activity

\begin{tabular}{llllll}
\hline (Constant) & -3.016 & 1.787 & -1.688 & 0.093 & 3.894 \\
\hline Evaluation of physical fitness & 0.263 & 0.067 & 0.246 & 3.961 & 0.000 \\
\hline Evaluation of work safety & 0.224 & 0.057 & 0.249 & 2.382 & 0.018 \\
\hline Age & 0.287 & 0.12 & 0.152 & 3.096 & 0.002 \\
\hline Working time during vacation & 0.005 & 0.001 & 0.205 & -2.521 & 0.012 \\
\hline Working time during a month & -0.008 & 0.003 & -0.166 & -2.027 & 0.044 \\
\hline Evaluation of severity of work & -0.094 & 0.046 & -0.132 & & \\
\hline
\end{tabular}


Table 4. Models of predictors for adolescents' evaluations of the effect of work performed by them on own health in the group of rural inhabitants (results of stepwise linear regression)

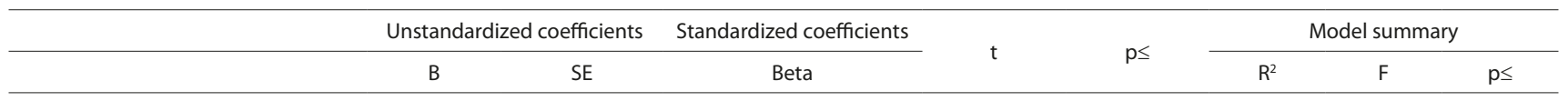

Model of predictors for the health effect of hired labour

\begin{tabular}{|c|c|c|c|c|c|c|c|c|}
\hline (Constant) & 1.654 & .239 & & 6.924 & 0.000 & & & \\
\hline Evaluation of work safety & .198 & .044 & .220 & 4.494 & 0.000 & & & \\
\hline Evaluation of physical fitness & .164 & .061 & .132 & 2.686 & 0.008 & 0.094 & 9.953 & 0.001 \\
\hline Body weight & -.010 & .004 & -.145 & -2.970 & 0.003 & & & \\
\hline Motivation for work - pressure & .210 & .092 & .112 & 2.289 & 0.023 & & & \\
\hline
\end{tabular}

Model of predictors for the health effect of work in family business

\begin{tabular}{|c|c|c|c|c|c|c|c|c|}
\hline (Constant) & 1.292 & .113 & & 11.401 & 0.000 & & & \\
\hline Evaluation of work safety & .254 & .041 & .236 & 6.224 & 0.000 & 0.103 & 25.029 & 0.001 \\
\hline Motivation for work - development & -.318 & .080 & -.150 & -3.968 & 0.000 & & & \\
\hline Self-reported state of health & .172 & .048 & .137 & 3.604 & 0.000 & & & \\
\hline
\end{tabular}

Model of predictors for the health effect of independent economic activity

\begin{tabular}{|c|c|c|c|c|c|c|c|c|}
\hline (Constant) & 1.454 & .105 & & 13.788 & 0.000 & & & \\
\hline Evaluation of work safety & .158 & .051 & .184 & 3.092 & 0.002 & 0.030 & 9.559 & 0.002 \\
\hline
\end{tabular}

with evaluation of the effect of these work activities on health as positive, whereas a more negative evaluation of the state of health was related with a more negative evaluation these work activities had on health.

In the group of adolescents living in rural areas, the evaluation of safety of work activities performed was also important: if the activities were evaluated as less safe, the more negative the evaluation of their effect on health. Work safety was not significantly related with evaluation of the effect of work on health in the group of adolescents living in urban areas. However, in this group, two other variables were important: evaluation of the severity of work activities performed, and involvement in an accident at work. In the case of urban adolescents, the effect of work in family business on health was evaluated in more negative terms when these activities were evaluated as severe, or when the respondents had previously been involved in an accident at work.

In both groups of rural and urban adolescents, analysis aimed at identification of the factors shaping the evaluation of the effect of independent economic activity on health generated statistically significant models which, however; differed considerably. In the case of rural adolescents, the model contained only one variable, whereas in the case of adolescents living in urban areas, the model contained six variables significantly related with this evaluation. In the group of rural adolescents, the predictors jointly explained $3.0 \%$ of variance of the dependent variable, while in the group of urban adolescents - $15.3 \%$. A significant predictor of the evaluation of the effect of independent economic activity on own health was only the evaluation of safety in these activities - the more hazardous the work, the more negative the evaluation of the effect of work on health. Urban adolescents evaluated the effect of independent economic activity on own health as more negative when they were at an older age, when they considered independent activity as more hazardous, or when they devoted a larger amount of time to this type of work. In addition, a more negative evaluation of the effect of work on health was related with devoting, during the month preceding the study, less time to work and evaluation of work activities as less severe.

\section{DISCUSSION}

The analysed performed show that the majority of Polish adolescents aged 14-15 evaluated as positive the effect of own economic activity on health. Positive evaluations, to a similar degree, concerned all types of work activities considered in the study. The evaluation observed in this study is especially favourable, compared to the results of other studies, e.g. those conducted in the Institute of Rural Health (IMW), concerning the health consequences in the work of children on family farms. The study of adults from agricultural families indicated that only $30 \%$ of respondents perceived a positive relationship between work performed during childhood and health of the child performing this work [25]. In turn, the study conducted among farmers' children aged 12-14 showed that the majority of respondents (56\%) negatively evaluated the effect of work on their health, and declared that work on a family farm created hazards for their health and life, while only 1/5 of respondents did not perceive such risks [12]. Differences in evaluations of the effect of work of the underaged on their health may result from the fact that the quoted research was conducted at various periods of time, relatively distant from each other, and concerned employment of the underaged living in areas with a high proportion of agricultural production.

Studies by the IMW referred to the situation of children at the beginning of the $21^{\text {st }}$ century, and the years from 1960s 1990 s of the $20^{\text {th }}$ century. During these periods, the methods of agricultural production were considerably different from those applied on contemporary family farms. This concerns mainly mechanization, which decreased the demand for a workforce in agriculture. Experiences of many countries show that changes in the technology of work, including mechanization of work, played an important role in the 
limitation of children in work [26]. Over several decades, the attitudes of parents with respect to the role of a child in a family have also changed. According to F. Adamski, a child obtains an increasingly higher position in a family [27]. The way of treating a child changes. A child is no longer perceived from the aspect of economic value, and becomes a value in his/her own right. Thus, it should be presumed that children and adolescents from contemporary families, to an increasingly lesser extent, undertake economic activity because of parents' expectations, and increasingly more often this results from their interests, and approaching work as an element of professional and economic education. The described changes may explain a relatively high acceptance by the examined adolescents of the opinion that work exerts a positive effect on health.

Analyses performed in the whole group in the study demonstrated that in the case of each type of work considered in the study, the factor which exerted the greatest effect on the perception of a given work activity as negatively affecting health, was evaluation of the dangers and hazards related with this work: the more dangerous and hazardous the work, the more negative the evaluation of its effect on health. In addition, self-reported state of health and physical fitness are of great importance for the evaluation of the effect of work on health: the more negative this evaluation, the more negative the evaluation of the effect of work on health. This result shows that adolescents who are less fit physically and have a worse state of health are less vulnerable to the negative effects of the work activities performed.

Evaluation of the effect of work on health is also shaped by assessment of its severity and previous involvement in an accident at work (with respect to work activities performed for the benefit of a family business or family farm): the performance of work considered as severe, and the fact of being a victim of an accident, favour evaluation of the work performed as exerting a negative effect on health. With respect to work on behalf of a family business or family farm, an indication of own development as the factor motivating for undertaking this work predisposes to the perception of work as more positively affecting health. Unexpected, although very interesting, is the result of analyses showing that a longer time of work during summer vacation within independent economic activity is related with the evaluation of this activity as exerting a more positive effect on health.

Linear regression analysis demonstrated that gender and place of residence (urban /rural) are not related with the fact how adolescents evaluate the effect of work on health. However, it occurred that the conditioning of evaluations of the effect of work on health differred between the groups of adolescents from urban and rural areas.

Analyses conducted separately in the groups of rural and urban adolescents demonstrated that variables considered in the regression models explain a slightly wider scope of variance of the variable 'assessment of the effect of work on health' in the case of urban than rural adolescents, especially with respect of assessment of the effect of independent economic activity on health (in the group of adolescents living in rural areas, the variables explain 3.0\% of variance of the effect of work on health, whereas in the group of urban adolescents - 15.3\%).

The most frequently occurring predictor explaining the evaluation of the effect of work on health (which occurs in the case of all types of work activity analyzed in the group of rural adolescents, and in the case of two work activities in the group of urban adolescents) is evaluation of safety in this work. Perception of dangers and threats related with a given work activity favours its assessment as negatively affecting health. Evaluation of safety of work among rural adolescents is the strongest predictor explaining all analyzed evaluations of the effect on health. The subsequent important factor explaining adolescents' evaluations of the effect of individual types of work is own physical fitness, to which contribute: evaluation of own physical fitness, self-reported health, and body weight. More negative parameters of these indicators are associated with more negative evaluation of the effect of work on health in the groups of both rural and urban adolescents (in the case of all types of work activities, except for independent economic activity among rural adolescents).

With respect to evaluation of the effect of hired labour, work performed in a family business or on a family farm, motivation for undertaking a given job is important, both among rural and urban adolescents. The indication by rural and urban adolescents of own development as the motive for undertaking work activities is related with the assessment of the effect of these activities as more positive. However, among rural adolescents, the indication of pressure from the environment as the motive for undertaking hired labour is related with the evaluation of these work activities as exerting a more negative effect on health.

In the group of urban adolescents undertaking work in a family business or on a family farm, it was found that the involvement in an accident at work intensified the negative evaluation of the effect of this work on health. This factor had no importance in the shaping of opinions of rural adolescents.

Unexpected and surprising relationships were found in the group of urban adolescents who undertook independent economic activity, between working time and evaluation of the effect of work on health. Although seemingly in accordance with expectations, a longer working time during the summer vacation was related with evaluation of these work activities as exerting a more negative effect on health, it occurs that a longer time devoted to this type of work in the month preceding the study was related with a more positive evaluation of the effect of work on health. Similarly, with respect to the severity of the work performed: although the analyses performed in the whole group showed that in the group of urban adolescents, the perception of work activities as severe was related with a more negative evaluation of its effect on health, in the case of independent economic activity, the performance of severe work was associated with a more positive evaluation of the effect of this work on health.

An explanation for the differences in the conditioning of evaluations by urban and rural adolescents concerning the effect of work on their health should be sought in the tremendous variation in work activities performed by the examined adolescents from both environments during the periods covered by the study. Attention should be paid to the specific situation of rural adolescents, whose economic activity, to a great extent, concentrates on work in agriculture, mainly on a family farm, thus on work including various activities, using machinery, technical equipment, and chemical agents [28]. In addition, in agriculture, workplaces, equipment and machinery are adjusted to adults, and do not take into consideration the psychophysical capabilities of the underaged [29]. Such work activities create various risks for health, or even life, of those who perform them. At the same 
time, urban adolescents, especially those who live in large cities, compared to urban adolescents, possess considerably better possibilities for undertaking hired labour which is lighter and less hazardous.

\section{CONCLUSIONS}

Endowment to the underaged of work providing income or earnings for themselves or their families often causes concerns, whether these work activities are adequate to their psychophysical capabilities or create a threat to their health. The objective of the study was recognition of adolescents' opinions concerning the effect of work on their health, and identification of factors which shape these opinions. The majority of respondents evaluated these work activities as exerting a positive or rather positive effect on health. The performed analysis of the conditioning of opinions concerning the effect of work on health allowed the identification of factors which shape these opinions.

The results of the study allow better understanding of the phenomenon of economic activity of adolescents and determination of the factors shaping adolescents' opinions concerning the effect of the work performed on their health. These results may be used for the elaboration of practical recommendations in order to reduce negative effects, and enhance positive effects which work exerts on adolescents' health. Recognition of the opinions pertaining to the effect of work on health from the perspective of working adolescents provides new information, and also allows an understanding of the relationship between work and health from the point of view of young persons who are preparing for assuming occupational roles. This is of great importance from the aspect of shaping employment policy, as well as from the aspect of shaping the policy for the protection of the health of children and adolescents.

The developed models of the conditioning of adolescents' opinions concerning the effect of work on health demonstrated that the identified factors, to a relatively low extent, explain these evaluations. This means that other variables, which have not been considered in these analyses, are also related with the evaluations. Therefore, there is a need to conduct further studies which take macrostructural and personality variables into consideration.

The limitation of the study is its correlational character. Longitudinal research might allow better understanding of the factors explaining the effect of work on health, and establishment of the cause-effect relationships between the analyzed factors.

\section{Acknowledgement}

The study was financed by the National Science Centre, Krakow, Poland (Project No. UMO-2014/15/B/HS6/03534).

\section{REFERENCES}

1. Cunningham H. The Employment and Unemployment of Children In England c. 1680-1851. Past and Present 1990; 126: 115-150.
2. The End of child Labour: Within Reach. Global Report under the followup to the ILO Declaration on Fundamental Principles and Rights AT Work. ILO. Geneva 2006.

3. Diallo Y, Etienne A, Mehran F, Global child labour trends 2008-2012. ILO. Genewa 2013;

4. Global Estimates of Child Labour. Results and trends, 2012-2016. ILO. Geneva 2017.

5. Admassie. A. Child labor and schooling In the context of a subsistence rural economy: can they be compatible? Int J Educ Develop. 2003; 23: 167-185.

6. Cigno A, Rosati FC, Guarcello L. Does Globalization Increase Child Labor? World Development 2002; 130: 1579-1589.

7. Kodeks pracy. Dz.U. 2018 poz. 917.

8. Ustawy z dnia 7 września 1991 r. o systemie oświaty. Dz. U. z 2004 r. Nr 256, poz. 2572 (teks jednolity z późn. zm).

9. Wypadki przy pracy i choroby zawodowe rolników oraz działania prewencyjne KRUS w 2003 roku. KRUS. Warszawa 2004.

10. Lachowski S, Zagórski J. Obciążenie praca dzieci z rodzin rolniczych. Zmiany w ostatnim dziesięcioleciu. IMW. Lublin 2010.

11. Lachowski S, Zagórski J. Child labour for the benefit of the family in rural Poland. Ann Agric Environ Med. 2011; 18 (2): 25-31.

12. Florek M, Lachowski S, Sosnowska S. Zagrożenia związane $z$ wykonywaniem przez dzieci prac rolnych w opinii uczniów szkół wiejskich województwa kujawsko-pomorskiego. Wieś i Rolnictwo 2010; 1 : 48-58.

13. Lachowski S. Praca dzieci w rodzinach wiejskich Lubelszczyzny. Uwarunkowania i zagrożenia, IMW Lublin, 2013.

14. Yotopoulos PA, Kuroda M. A subjective equilibrium approach to the value of children in agricultural household The Pakistan Development Rev. 1988; 27(3): 229-276.

15. Lachowski S. Znaczenie pracy dzieci dla funkcjonowania rodziny rolniczej. W: Współczesna rodzina polska. Przemiany, zagrożenia, wyzwania. Red. A. Jabłoński. M. Szyszka, D. Gizicka. KUL Lublin 2014; $115-127$.

16. Sobieraj W. Socjalizacja ekonomiczna dzieci jako czynnik rozwoju kapitału ludzkiego. Nauki Społeczne 2013; 2(8): 183-193.

17. Lieten GK. Child Labour and Poverty. In: Working Children Around the Working Child Rights and Child Reality Red. G.K. Lieten. IREWOC Foundation and Institute for Human Development. Amsterdam, New Delhi 2004: 63-80.

18. Bytniewski M. Fizjologiczne aspekty pracy fizycznej dzieci I młodzieży wiejskiej. In: Zagrożenia zdrowia dzieci angażowanych do prac w rodzinnym gospodarstwie rolnym. Lachowski S, Zagórski J (eds). IMW. Lublin 1999; 31-47.

19. Contribution des enfants au travail de la terre et á sa preservation: Les liens entre l'agriculture et les droits de l'enfant Agence canadienne de dèveloppement international. Canada 2006.

20. Al.-Gamal E, Hamdan-Mansour AM, Matrouk R, Al Nawaiseh M. The psychosocial impact of child labour in Jordan: A national study. Int J Psychol. 2013; 48(6): 1156-1164.

21. Polakoff EG. Globalization and Child Labor: Review of the Issues. J Develop Soc. 2007; 23(1-2): 259-283.

22. Roggero P, Mangiaterra V, Bustreo F, Rosati F. The Health Impact of Child Labor in Developing Countries: Evidence From Cross-Country Data. Am J Public Health. 2007; 97(2): 271-275 Available from: https:// www.researchgate.net/publication/6605674_ [accessed Jul 18 2018].

23. Aktywność ekonomiczna ludności Polski - I - IV kwartał 2008 r. GUS. Warszawa 2009

24. Dedyńska S, Książek M. Statystyczny drogowskaz 3. Praktyczny przewodnik wykorzystania modeli regresji oraz równań strukturalnych. Warszawa 2012.

25. Lachowski S. Health consequences of work in childhood in opinions of respondents from agricultural families. Ann Agric Environ Med. 2013; 20(3): 624-630.

26. Basu K. Child Labor: Cause, Consequence, and Cure, with Remarks on International Labor Standards. J Econ Lit. 1999; 37: 1083-1119.

27. Adamski F. Rodzina. Wymiar społeczno-kulturowy. UJ. Kraków 2002.

28. Zagrożenia zdrowotne i wypadkowe a BHP w rolnictwie. Bujak F, Choina P, Jurkiewicz A (eds). Lublin 2014.

29. Lachowski S. Praca dzieci w rodzinnym gospodarstwie rolnym problem dostosowania prac do możliwości dziecka. In: Ergonomia, bezpieczeństwo i higiena pracy w praktyce. Pawlak H. (ed). Uniwersytet Przyrodniczy w Lublinie. Lublin 2016: 56-67. 